\title{
Spatial Model of Deforestation in Sumatra Islands Using Typological Approach
}

\author{
Nurdin Sulistiyono ${ }^{1,2 *}$, Nengah Surati Jaya ${ }^{3}$, Lilik Budi Prasetyo ${ }^{4}$, Tatang Tiryana ${ }^{3}$ \\ 'Graduate School of Bogor Agricultural University, Dramaga Main Road, Campus IPB Dramaga, Bogor, Indonesia 16680 \\ ${ }^{2}$ Department of Forestry, Faculty of Agriculture, North Sumatra University, Medan, Indonesia 20155 \\ ${ }^{3}$ Department of Forest Management, Faculty of Forestry, Bogor Agricultural University, Academic Ring Road, Campus IPB \\ Dramaga, PO Box 168, Bogor, Indonesia, 16680 \\ ${ }^{4}$ Department of Forest Conservation and Ecotourism, Faculty of Forestry, Bogor Agricultural University, Academic Ring \\ Road, Campus IPB Dramaga, Bogor, Indonesia 16680
}

Received May 4, 2015/Accepted August 26, 2015

\begin{abstract}
High rate of deforestation occurred in Sumatra Islands had been allegedly triggered by various factors. This study examined how the deforestation pattern was related to the typology of the area, as well as how the deforestation is being affected by many factors such as physical, biological, and socio-economic of the local community. The objective of this study was to formulate a spatial model of deforestation based on triggering factors within each typology in Sumatra Islands. The typology classes were developed on the basis of socio-economic factors using the standardized-euclidean distance measure and the memberships of each cluster was determined using the furthest neighbor method. The logistic regression method was used for modeling and estimating the spatial distribution of deforestation. Two deforestation typologies were distinguished in this study, namely typology 1 (regencies/cities with low deforestation rate) and typology 2 (regencies/cities with high deforestation rate). The study found that growth rate of farm households could be used to assign each regencies or cities in Sumatra Islands into their corresponding typology. The resulted spatial model of deforestation from logistic regression analysis were logit (deforestation) = $1.355+(0.012 *$ total of farm households $)-(0.08 *$ elevation $)-(0.019 *$ distance from road $)$ for typology 1 and logit $($ deforestation $)=1.714+(0.007 *$ total of farm households $)-(0.021 *$ slope $)-(0.051 *$ *levation $)-(0.038 *$ distance from road $)+(0.039 *$ distance from river $)$ for typology 2 , respectively. The accuracy test of deforestation model in 2000-2006 showed overall accuracy of 68.52\% (typology 1) and 74.49\% (typology 2), while model of deforestation in 2006-2012 showed overall accuracy of 65.37\% (typology 1) and 72.24\% (typology 2), respectively.
\end{abstract}

Keywords: deforestation model, logistic regression, typology, Sumatra Islands

*Correspondence author, email: nurdinsty2013@gmail.com,ph.: +62-81375461931

\section{Introduction}

Tropical forests in Sumatra Islands have enormous benefits in social, economic, cultural, political, and ecological aspects. To describe the enormous benefits of forests in the Islands of Sumatra, Van Beukering et al. (2003) reported that the total economic value of Gunung Leuser National Park (GLNP) is USD316 million year ${ }^{-1}$, which represents total value of economic benefits of water supply, fisheries, flood control, agriculture, energy, ecotourism, biodiversity, carbon storage, forest fire prevention, nontimber forest products, and timber forest products. Forests of Sumatra are also the habitat of more than 10,000 species of plants, 201 species of mammals, and 580 species of avifauna (Whitten etal.2000).

The forests in the island continue to experience pressure as the forest cover continually declines every year. Data issued by the Ministry of Forestry mentioned that forest cover in 2011 was 14.84 million ha (MoF 2012) then declined in 2012 to 13.97 million ha (MoF 2014). According to data released by Forest Watch Indonesia (FWI), Sumatra as one of the major islands in Indonesia was experiencing high rates of deforestation at 412,421.9 ha year ${ }^{-1}$ (Sumargo et al. 2011). Large-scale deforestation in the tropics for the provision of agricultural lands was one example of land use changes that has a major impact on biodiversity, land degradation, and the earth's ability to support human needs (Lambin et al. 2003). The impacts of deforestation and degradation of tropical forests in the form of forest destruction have become an important global issue due to the magnitude of cumulative impacts on biodiversity, soil productivity, and global climate (Geist \& Lambin 2001; Laurance et al. 2014).

Geist \& Lambin (2002) have conducted a study on deforestation in tropical forests, including in Indonesia. The study found that the main factors that drive deforestation in tropical forests were land expansion for agriculture, logging, 
and infrastructure development. Meanwhile, the underlying factors were economic, institutions and policies, technological, social, cultural, population growth, as well as other factors such as land characteristics, biophysical properties of crop/land, and social unrest. Indonesia as an archipelago country with a variety of forest biophysical ecosystem characteristics and different socio-economic conditions of its people, have a diverse driving force of deforestation in each region.

The studies conducted by Allen and Barnes (1985), Meyer and Turner (1992), also Pahari and Murai (1999) stated that land use changes, including deforestation on a global scale were driven by population growth. Quantitative research that mention common factors such as wealth and population growth as the main cause of deforestation considered has ignoring the specific factors such as biophysical factors, proximity, and other socio-economic factors (Rudel 2007). In regards to related policies, this simplification in which the driving forces of deforestation considered as the same for any region was considered inappropriate.

Administratively, Sumatra is divided into 10 provinces and 93 regencies/cities with a total area of 47,322,331.3 ha. The types of forest landscapes in each administrative region in the island are specific in characteristics and diverse in problems. Consequently, the driving forces that triggers the occurrence of deforestation in each administrative region in Sumatra were also varies. Hence, it was necessary to investigate further on the driving forces for different regencies, i.e. based on their typology. Typology was defined as a classification or grouping of objects based on similarity of the basic traits into certain types. This definition is modified from the Oxford English Dictionary (Soares \& Stevenson 2009).

Several researches on the spatial model of deforestation have been conducted in some locations in the island, including Melati (2012) in Riau Province, Mulyanto and Jaya (2004) in the forest concessionaires of PT Duta Maju Timber West Sumatra Province, as well as Linkie et al. (2004) in the Tapan Hill, Jambi Province. However, studies on spatial model of deforestation for a large extent using typological approach in Sumatra have never been conducted. Considering its potential information to be generated, this study may provide input in the preparation of deforestation mitigation policies and strategy of baseline formulation in REDD+ mechanism in Indonesia in general, as well as in the Islands of Sumatra in particular. The aim of this study was to develop a spatial model of deforestation based on the driving force for each typology in Sumatra Islands.

\section{Methods}

Data Terra MODIS MOD13Q1 satellite image data used in this research was acquired in 2000, 2006, and 2012 with $250 \mathrm{~m}$ spatial resolution. The band combination used were middle infrared (MIR) band on the red layer, near infrared (NIR) band on the green layer, and blue band on the blue layer (Wedastra et al. 2013), while selection of good pixel data were based on the band information that determines the image quality of the Pixel Reliability and VI Quality bands
(Solano et al. 2010; Wedastra et al. 2013). The MIR, NIR, and blue band selection was based on the spectral characteristic of the objects, particulary related to forest and non-forest. The MIR band was superior in determining soil, NIR band has its advantage in vegetation determination, while blue band as a strong chlorophyll absorber may enhance the occurance of vegetation (Richards \& Richards 1999).

The other supporting data were administrative boundary map, road network map, river network map, digital elevation model from Shuttle Radar Topographic Mission, and statistical data of social economic for each regency/city from Bureau of Statistic Service in Sumatra Islands for the period 2000-2012.

Deforestation identification Deforestation in this study was defined as forest cover changes into permanent non-forest. In this study, the forest land cover changes into timber estates were not included in the calculation of deforestation, because logging activities in timber estates is a regular activity that is not permanently occurred. The analysis of land cover classification on Terra MODIS satellite images was performed using supervised classification approach (Otukeia \& Blaschke 2010; Churches et al. 2014) with maximum likelihood classifier. The detection of forest land cover changes was performed using post-classification comparison method (Abd El-Kawy et al. 2011; Huiping et al. 2011; Were et al. 2013). This post-classification comparison technique was conducted using 2 images that have been classified separately. Comparisons were conducted pixel by pixel to obtain detailed data on the occurance of forest cover changes.

Determination on typology of deforestation In this study, regency/city was considered as the smallest unit to define the typology of deforestation. The typologies were built based on clustering approach. In theory, cluster analysis is a multivariate technique that has the main purpose to categorize objects based on their own characteristics. Cluster analysis classifies objects, thus each object that has the closest similarity to other objects are classified in the same cluster. The formed clusters should have high internal homogeneity and high external heterogeneity (Ediyanto et al.2013).

In details, standardized euclidean distance (SdED) was used to perform cluster analysis. The use of SdED was based on the difference in the range of values and the difference in variable units used in the typology determination. The distance between 2 data was calculated using equation as described in Equation [1]:

$$
S d E D_{J K}=\left[\sum_{i=1}^{n} \frac{\left(x_{i j}-x_{i k}\right)^{2}}{S_{i}^{2}}\right]
$$

note:

$S_{\mathrm{i}}=$ the diversity of $\mathrm{i}$-th variable

$X_{\mathrm{ij}}=$ the value of $\mathrm{i}$-th variable from cluster $\mathrm{j}$

$X \mathrm{ik}=$ the value of $\mathrm{i}$-the variable from cluster $\mathrm{k}$

Socio-economic factors of population density (Entwisle et al. 2008; Prasetyo et al. 2009; Romijn et al. 2013), number of farm households (Pacheco 2006; Prasetyo et al. 2009), number of poor people (Khan \& Khan 2009) and Gross 
Regional Domestic Product (GDP) (Romijn et al. 2013) were predicted to be the sosio economic driving forces of deforestation. Therefore those factors were used to characterize a regency/city and determine its typology. In addition, the rate of deforestation was used to validate the typology categorization for each regency.

Accuracy assessment of typology of deforestation The accuracy assessment on typology of deforestation was performed by calculating the overall accuracy between clustering result and deforestation rate of each regency/city in Sumatra. The deforestation rate was resulted from the analysis of land cover classification using satellite image of Terra MODIS MOD13Q1. The formula of deforestation rate was based on the formula developed by Fearnside (1993) as shown in Equation [2].

$$
r=\frac{A_{1}-A_{2}}{t_{1}-t_{2}}
$$

note:

$r=$ deforestation rate

$t_{2}=$ final year

$t_{1}=$ first year

$A_{2}=$ forest area at final year

$A_{1}=$ forest area at first year

Determination of deforestation spatial model Binary logistic regression analysis (Linkie et al. 2004; Mulyanto \& Jaya 2004; Prasetyo et al. 2009; Arekhi 2011; Arsanjani et al. 2013) was used to obtain the deforestation model. The driving forces such as socio-economic data, as well as biophysical and cultural factors were used as independent variables in the model. The selection process of driving forces in deforestation was conducted using the stepwise method by reducing or removing the driving factors that have no effect on the model.

Pixel samples were randomly selected to build a deforestation model in each typology. The dependent variables in logistic regression were binary, where the value of 1 meant there is change in forest land cover into non-forest and the value of 0 means there is no change in forest land cover during 2000-2006. The resulted regression equation was used to predict the probability of deforestation in the future (2006-2012).

Processing of binary logistic regression models was conducted using SPSS software. Socio economic factors $\left(\mathrm{X}_{1}-\mathrm{X}_{4}\right)$ were vector data with regencies/cities as a spatial unit which converted into raster format sized $250 \times 250 \mathrm{~m}$, and the data of biophysical driving factors $\left(x_{5}-x_{9}\right)$ were raster data having $250 \times 250 \mathrm{~m}$ pixel size.

In general, the logistic regression equation is formulated as shown in Equation [3].

$\pi(x)=\frac{\exp \left(\beta_{0}+\beta_{1}+\ldots+\beta_{p} x_{p}\right)}{1+\exp \left(\beta_{0}+\beta_{1}+\ldots+\beta_{p} x_{p}\right)}$

note:

$\beta_{0}=$ intercept

$\beta_{\mathrm{i}}=$ coefficient of variable $x_{\mathrm{i}}$

$\pi=$ probability of land changes $(0-1)$

$x_{1}=$ population density (inhabitants $\mathrm{km}^{-2}$ )

$x_{2}=$ the number of farming households (household) $x_{3}=$ number of poor (people)

$x_{4}=\mathrm{GDP}($ billion IDR)

$x_{5}=$ slope $(\%)$

$x_{6}=\operatorname{altitude}(\mathrm{m})$

$x_{7}=$ distance from the $\operatorname{road}(\mathrm{m})$

$x_{8}=$ distance from the river $(\mathrm{m})$

$x_{9}=$ distance from the settlements $(\mathrm{m})$

In the logistic regression model, the model is considered to be fit if the value of Hosmer-Lemeshow test shows a value bigger than $p$-value (0.05), while the contribution of predictor variables can be seen from the $\operatorname{Exp} \beta$ (odds ratio) value which is an exponential function of regression coefficient. The farther from 1 , the contribution of a variable will be greater, in contrary, the closer to 1 , the contribution of a variable in a model will be smaller (Hosmer \& Lemeshow 2000).

The independent variables ( $x$ variables) have different unit and scale, thus it is necessary to standardize the scores of each variable. The standardization process of $x$ variables was conducted by standardizing the values of each variable into the range of $0-255$ using the equation formulated by Jaya (2006) as shown in Equation [4].

Score $\mathrm{R}_{\text {out }}=\left[\frac{\operatorname{Score} E_{\text {input }}-\operatorname{Score} E_{\min }}{\operatorname{Score} E_{\max }-\operatorname{Score} E_{\min }}\right] \times\left(\operatorname{Score} R_{\max }-\operatorname{Score} R_{\min }\right)+\operatorname{Score} R_{\min } \quad$ [4]

note:

$R_{\text {out }}$ score $=$ score resulted from rescaling

$E_{\text {input }}$ score $=$ estimated score of input

$E_{\text {min }}$ score $=$ minimum value of estimated score

$E_{\max }$ score $=$ maximum value of estimated score

$R_{\max }$ score $=$ highest score resulted from rescaling $(255)$

$R_{\text {min }}$ score $=$ lowest score resulted from rescaling $(0)$

In order to observe the association of each independent variables, multi collinearity test was performed. Logistic regression model should avoid the use of multi collinear variables. The correlation coefficient between the predictors were calculated using the Pearson correlation coefficient. In this study, correlation coefficient of 0.65 was used as the limit for selecting variables as referred in (de Almeida et al. 2002; Aguayo et al. 2007).

The accuracy of spatial model of deforestation was assessed by comparing the deforestation prediction map with the actual deforestation map derived from the land cover classification of Terra MODIS image (image to image comparison). The process of transforming the results from deforestation model into raster data formats was performed using Arc GIS 9.3 software. In brief, the flowchart of model establishment is showed in Figure 1.

\section{Results and Discussion}

Land cover changes Interpretation results of Terra MODIS MOD13Q1 satellite image using digital classification showed that the forest area in the Islands of Sumatra was continued to decline. Forest area excluding the timber estates in 2000 was recorded at $12,150,500.0$ ha $(25.7 \%)$, then declined in 2006 to $10,398,324.8$ ha $(22.0 \%)$, and in 2012 continued to decline to $9,960,893.3$ ha $(21.0 \%)$. The deforestation rate in 2000-2006 was 292,029.2 ha year ${ }^{-1}$, whereas in 2006-2012 the deforestation rate decreased to 


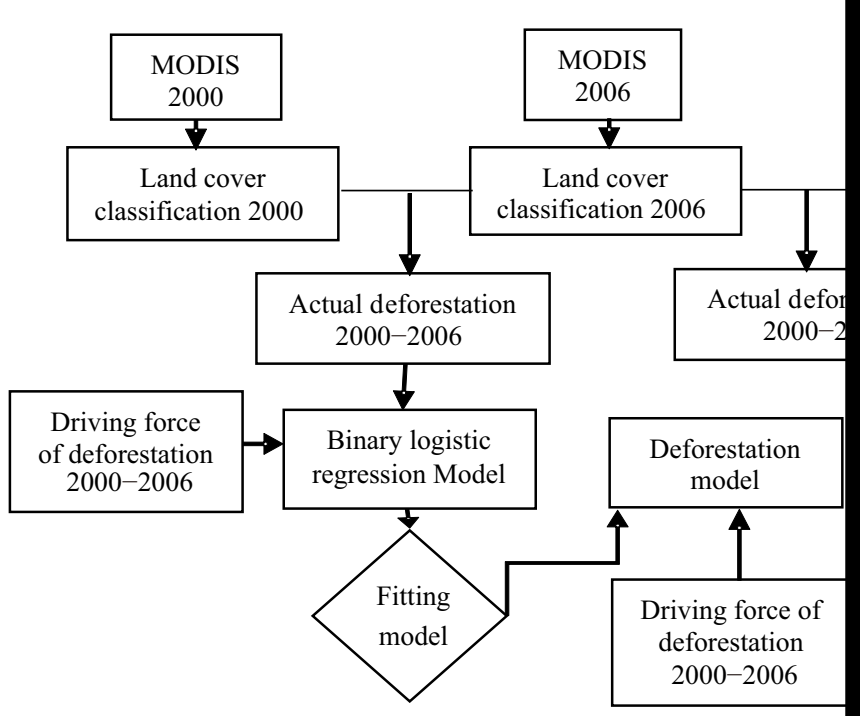

Figure 1 Flow charts stages of development of deforestation spatial models u

$72,905.3$ ha year $^{-1}$. These results were consistent with Sumargo et al. (2011) and Margono et al. (2012) which stated that land cover area in Sumatra was continued to decline every year.

Typology of deforestation Clustering results using number of farm households as a determining variable can be seen in Figure 2. Typology 1 was characterized by a relatively low rate of number of farm households as to compared with typology 2. In order to validate the clustering result (typologies), the rate of deforestation was used. This study found that the limiting threshold of low and high deforestation rate was at the magnitude of 2,562.7 ha year $^{-1}$. In other words, a regency having deforestation rate of $<$ 2,562.7 ha year ${ }^{-1}$ was categorized as low deforestation rate regency. Conversely, a regency having deforestation rate of $\geq$ 2,562.7 ha year ${ }^{-1}$ was categorized as high deforestation regency. In overall, the membership of clustered regencies and its corresponding rate of deforestation resulting accuracy of $73.1 \%$.

Based on the information in Figure 2, there were 63 regencies/cities that belonged to the typology 1 (low deforestation rates) and 30 regencies/cities that were members of the typology 2 (high deforestation rates). The average value of deforestation rate for typology 1 was $1,156.53$ ha year $^{-1}$ and for typology 2 was $3,968.81$ ha year $^{-1}$, respectively. Typology 1 was dominated by urban areas that relatively more advanced and regencies/cities that have relatively limited forest area. Meanwhile, typology 2 was dominated by regencies/city with relatively larger extend of forest area than those belonged to typology 1 .

The increase in the expansion of agriculture sector, particularly oil palm plantations in of Sumatra has believed as a maj Increasin accompan Thus, indi was one 0 were in lin which sta agricultur: deforestat

Spatial m binary $\log$ obtain the typology. showed th that there variable Y could be influencin value und that the dr typology (Table 1 significan $(>0.05)$ models w words, th models deforestat used.

There economic of defores
012

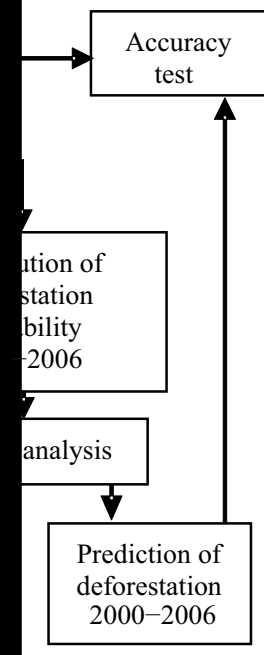

stic regression.

ding to high deforestation rate. lantation areas occasionally in the number of farm households. ase of number of farm households prces of deforestation. This results al. (2015) and Setiawan et al. (2015 gh rate of forest conversion into on in Sumatra has led to high ea.

station Table 1 shows the results of analysis using stepwise method to eforestation probability for each sults in typology 1 and typology 2 (sig) value of 0.000 , which means nne predictor variable that affects pothesis rejected) so that the model er. The test results on each of the ial test) also showed a significant ected), thus it could be interpreted leforestation both in typology 1 and gnificant influence on the model test using Hosmer-Lemeshow gy 1 deforestation model was 0.959 2 was $0.468(>0.05)$, thus both t or worthy $\left(\mathrm{H}_{0}\right.$ accepted). In other gnificant differences between the servation values, so that the could be accepted or feasible to be

$\mathrm{s}$ in the number and types of socio1 factors that trigger the occurrence gy 1 and typology 2 (see Table 1). 
Dendrogram using complete linkage

Rescale distance cluster combine
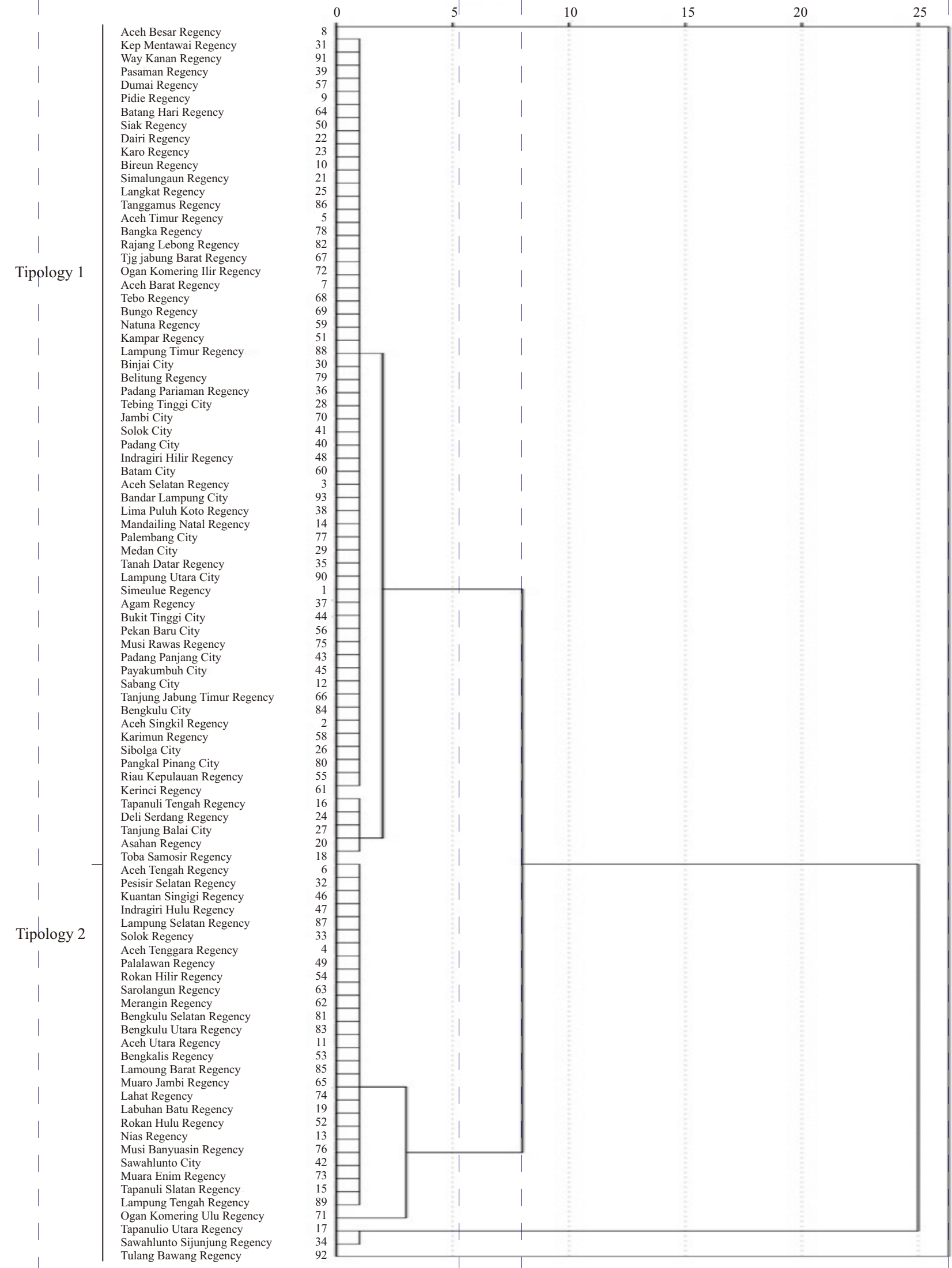

Figure 2 Dendogram of regency/city clustering using increase rate of the number of farming households. 
Table 1 Statistical test of deforestation models in typology 1 and typology 2

\begin{tabular}{|c|c|c|c|c|c|c|}
\hline Typology & Variable & $\beta$ & Sig. & $\operatorname{Exp}(\beta)$ & $\begin{array}{c}\text { Nagelkerke } \\
\text { R Square }\end{array}$ & Hosmer and Lemeshow Test \\
\hline \multirow[t]{4}{*}{1} & $x_{2}$ & 0.011 & .000 & 1.012 & \multirow{4}{*}{0.605} & \multirow{4}{*}{0.959} \\
\hline & $x_{6}$ & 0.006 & .000 & 0.923 & & \\
\hline & $x_{7}$ & 0.070 & .000 & 0.981 & & \\
\hline & Constant & 0.019 & .000 & 3.876 & & \\
\hline \multirow[t]{6}{*}{2} & $x_{2}$ & 0.007 & .000 & 1.007 & \multirow{6}{*}{0.641} & \multirow{6}{*}{0.468} \\
\hline & $x_{5}$ & 0.021 & .000 & 0.979 & & \\
\hline & $x_{6}$ & 0.051 & .000 & 0.950 & & \\
\hline & $x_{7}$ & 0.038 & .000 & 0.963 & & \\
\hline & $x_{8}$ & 0.039 & .000 & 1.040 & & \\
\hline & Constant & 1.714 & .000 & 5.551 & & \\
\hline
\end{tabular}

$x_{2}=$ number of farming households, $x_{5}=$ slope, $x_{6}=$ elevation, $x_{7}=$ distance from road, $x_{8}=$ distance from river

Deforestation occurred in typology 1 was influenced by factors such as number of farm households, elevation, and distance from the road, while in typology 2 was influenced by the number of farm households, slope, elevation, distance from the road, and the distance from the river. The value of $R$ squared in typology 1 was 0.605 , which means that $60.5 \%$ of the deforestation can be influenced by the number of farm households, elevation, and distance from the road, while the remaining percentage was influenced by other factors. $R$ squared value in typology 2 was higher than $R$-squared value in typology 1 at the magnitude of 0.641 , which means that the deforestation in typology 2 can be influenced by the number of farm households, slope, elevation, distance from the road, and distance from the river, while the remaining percentage was influenced by other factors.

In typology 1, elevation and distance from the road factors showed a negative correlation with the deforestation probability, while the number of farm households showed the opposite. Elevation factor has an odds ratio of 0.923 , which means that one unit increase of the elevation factor value will lower the deforestation probability by $7.7 \%$ (1$0.923)$; this value was the highest among other driving forces. Distance from the road factor has an odds ratio of 0.981, which means that one unit increase of the distance from the road will lower the deforestation probability by $1.9 \%(1-0.981)$, while the number of farm households has an odds ratio of 1.012, which means that one unit increase of the number of farm households value will raise the deforestation probability by $1.2 \%(1.012-1)$. Areas with low elevation values, close to the road and have a high number of farm households would have a high deforestation probability. The correlations between the driving forces of deforestation to the extent of deforestation probability in typology 1 can be seen in Figure 3.

In typology 2 , in which the regencies/cities having high deforestation rate, the driving forces of deforestation were more complex in comparison to typology 1 . It could be seen from many driving forces that played a role in typology 2 . Similar to typology 1, elevation, distance from the road and slope showed a negative correlation with deforestation probability, while distance from the river and number of farm households showed the opposite. In typology 2, elevation was the most contributed driving force to the deforestation probability model, followed by other factors such as distance from the road, slope, distance from the river and the number of farm households, respectively. The relationship between the driving forces with the intensity of deforestation probability in typology 2 is shown in Figure 4.

Similar to typology 1 , accessibility factors such as elevation and distance from the road have significant influence to deforestation in typology 2. Deforestation probability in areas having lower elevation, shorter distance from the road, flatter slope, away from the river, and have high number of farm households were predicted to have high probability of deforestation. On the contrary, areas having lower elevation, shorter distance from the road, near from the river but have high number of farm households and steeper slope were predicted by model as areas with low probability of deforestation.

Distance from the river in typology 2 was directly proportional to the deforestation probability, which means that deforestation in typology 2 was more commonly occurred in the forest area that far from the river as to compared to the forest area that close to the river. This happens due to the decrease in timber potential or forest areas in near the river. The phenomenon could be connected to many cases of deforestation occurred in the areas close to the river back in the $1970 \mathrm{~s}-1980 \mathrm{~s}$, where rivers were used to transport the timbers. The results are consistent with research Etter et al. (2006) which states that deforestation in the Amazon region in Colombia has a positive relationship with the distance from the river.

In typology 2, one of the driving forces of deforestation was the distance to the road, in which contributed to higher deforestation probability in comparison to in typology 1 . Areas belonged to typology 2 such as Riau Province has relatively more forest concessionaires (either active or inactive), where its road network was often used as means of illegal logging. Geist and Lambin (2002) suggested that the road construction could be a driving force of deforestation.

The study found that elevation was the most influencing driving forces towards the deforestation probability both in typology 1 and typology 2 . The contribution of elevation in typology 1 gave higher effect in comparison to the elevation contribution in typology 2. Low topographic forest areas in typology 1 were more potentially undergone deforestation in comparison to low topographic forest areas in typology 2 . Low topographic forest area in typology 1 such as in the east coast of North Sumatra Province was undergone massive forest conversion into oil palm plantations. Forests conversion to plantations in typology 2 occurred in areas with 


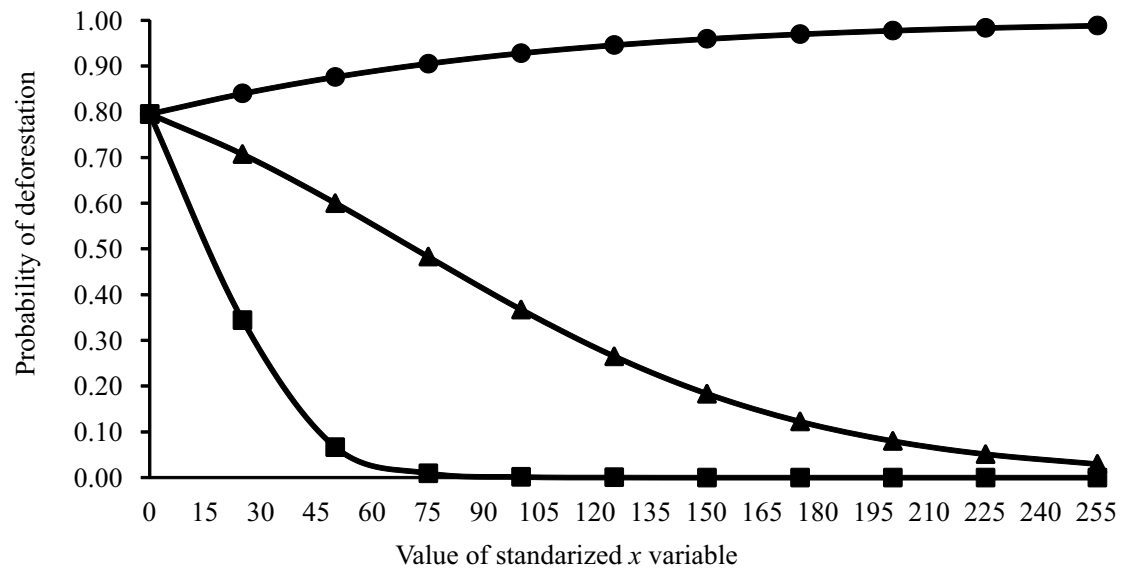

Figure 3 Relations of driving factor with probability of deforestation in typology 1 . Total of household farmer ( - -), elevation $(-)$, distance to road $(\longrightarrow)$.

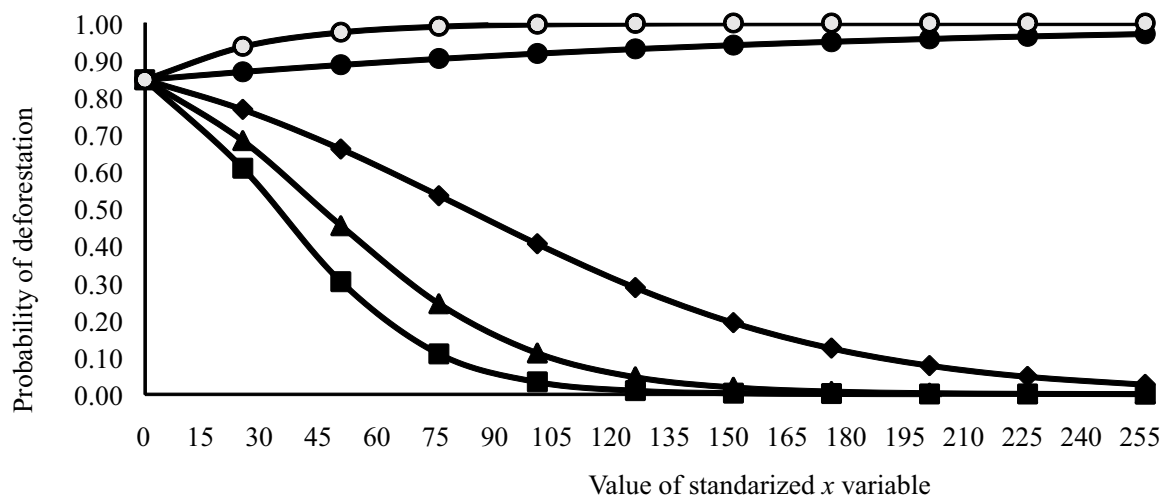

Figure 4 Relations of driving factor with probability of deforestation in typology 2. Total of household farmer ( - - elevation $(\rightarrow)$, distance to river $(-\infty)$, slope $(\longrightarrow)$, distance to road $(\longrightarrow)$.

low topography and flat slope as occurred in the eastern coastal of Riau Province. Elevation difference in typology 1 gave more influence on the deforestation probability as to compared with in typology 2 .

The deforestation models in typology 1 and typology 2 in this study were in line with the study results of deforestation models which mentioned that elevation factor and the closeness to the road were factors that affecting deforestation as built by Linkie et al. (2004) in the lowland forests of Sumatra Islands, Arekhi (2011) in the Northern Forest, Ilam Province. Iran and Kumar et al. (2014) in Kanker District, Chhattisgarh Province, India also mentioned that deforestation was inversely proportional to the distance from the road, slope and elevation.

The number of farm households in typology 1 provided a higher contribution to the deforestation probability when compared to typology 2 . This factor was directly proportional to the deforestation probability. This result showed that areas with a high number of farm households in typology 1 were more likely to undergo deforestation in comparison to those in typology 2 . This result was different from Prasetyo et al. (2009) which stated that the percentage of farm households has a negative correlation with the deforestation probability in Java Island.

Generally, models of deforestation probability in each typology was formulated as shown in Equation [5] and Equation [6].

1 Deforestation model in typology 1 :

$\Pi(x)=\frac{\exp \left(1.355+0.012 x_{2}-0.08 x_{6}-0.019 x_{7}\right)}{1+\exp \left(1.355+0.012 x_{2}-0.08 x_{6}-0.019 x_{7}\right)}$

2 Deforestation model in typology 2:

$\Pi(x)=\frac{\exp \left(1.714+0.007 x_{2}-0.021 x_{5}-0.051 x_{6}-0.038 x_{7}+0.039 x_{8}\right.}{1+\exp \left(1.714+0.007 x_{2}-0.021 x_{5}-0.051 x_{6}-0.038 x_{7}+0.039 x_{8}\right.}[6]$

Results of accuracy assessment on the actual deforestation in 2006-2012 showed the higher accuracy of typology 2 deforestation model than typology 1 . Both models were sufficient to be used to predict the future deforestation probabilities (in 2006-2012) with the overall accuracy of $65.37 \%$ for typology 1 and $72.24 \%$ for 
typology 2. The result of overall accuracy assessment in the deforestation probability models were smaller than similar study in Java Island conducted by Prasetyo et al. (2009), which obtained an overall accuracy of $88.70 \%$. However, spatial modeling on deforestation was part of a complex land-use change model, thus the accuracy of more than $85 \%$ was difficult to achieved (Huang et al. 2007).

Distribution value of deforestation probability during 2006-2012 in typology 1 was ranged between close-to-0 to
0.9533 (Figure 5a), while the distribution value of deforestation probability during 2006-2012 in typology 2 was ranged between close-to-0 to 0.9859 (Figure 6a). If the probability of deforestation less than 0.5 , then it was classified as a non-deforestation, whereas if the probability of deforestation is higher than or equal to 0.5 then it was classified as a deforestation. The predictive deforestation maps of both typologies were depicted in Figure 5b and Figure 6b.

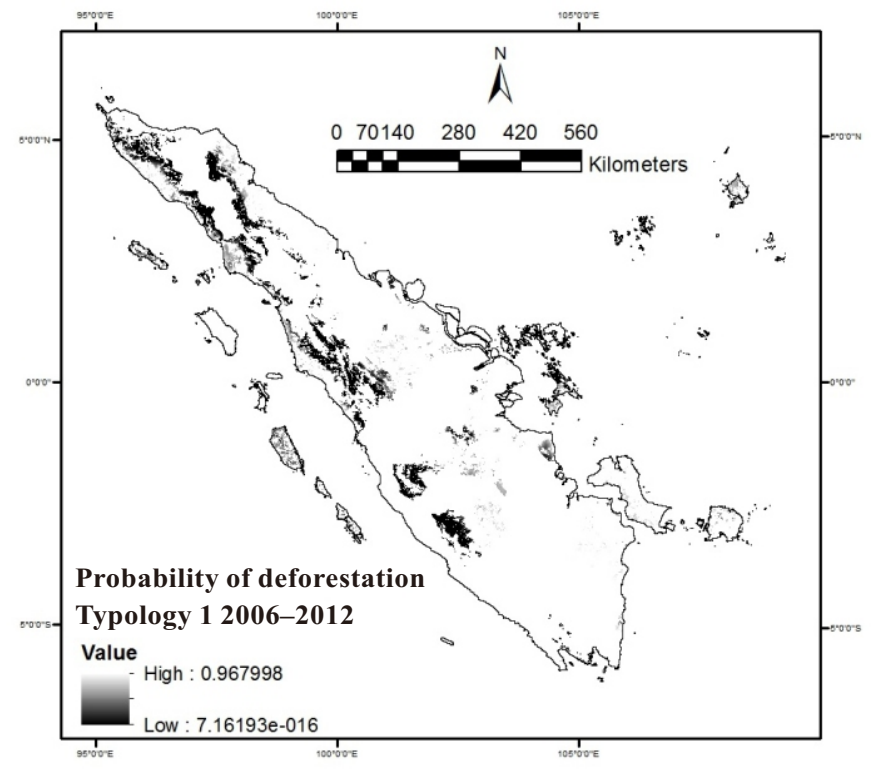

(a)

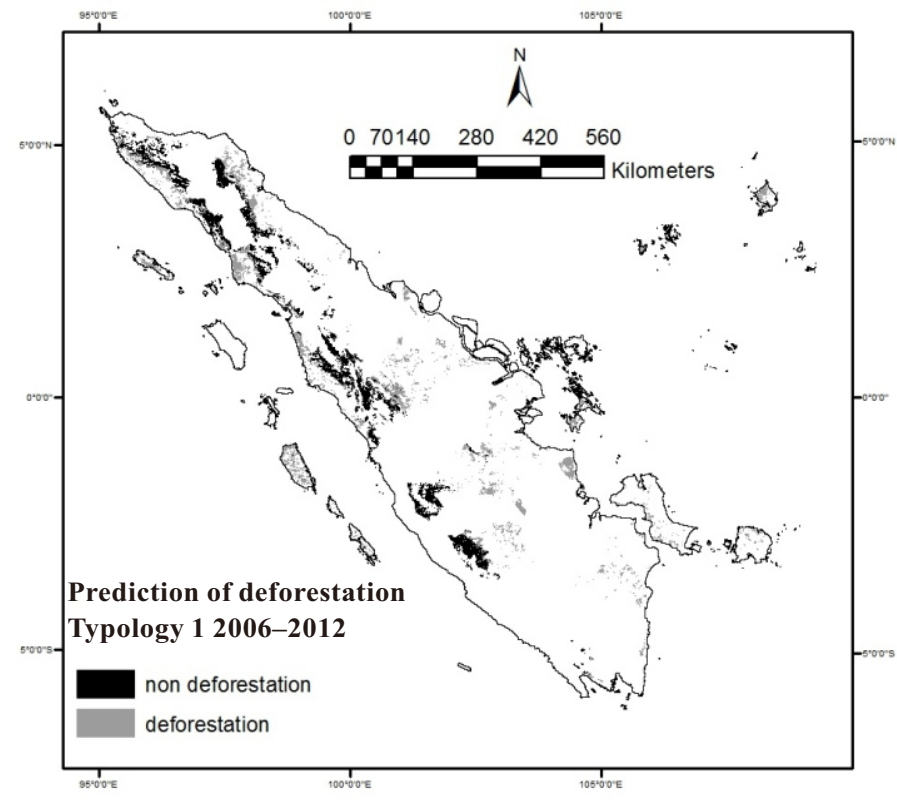

(b)

Figure 5 The distribution of deforestation probability of typology 1 in 2006-2012 based on a logistic regression model (a), Deforestation predicticve model of typology 1 in 2006-2012 based on a logistic regression model (b).

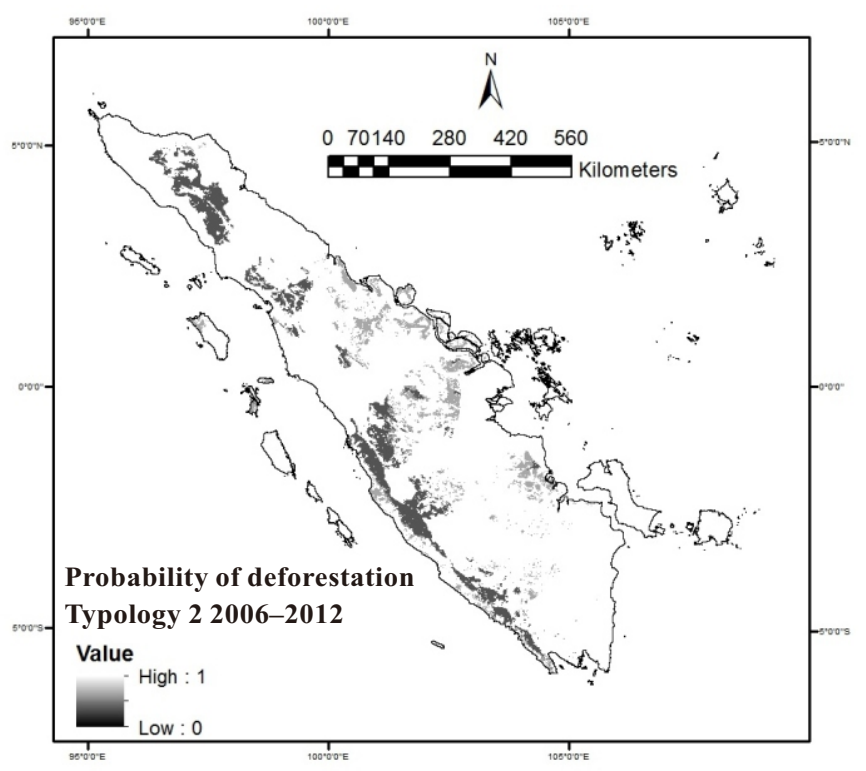

(a)

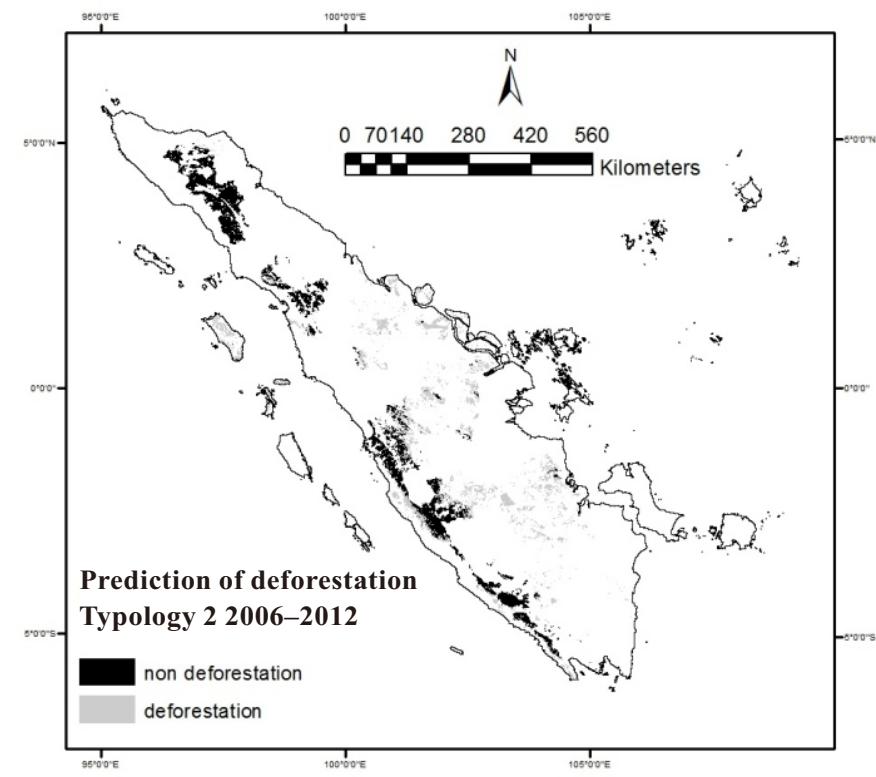

(b)

Figure 6 The distribution of deforestation probability of typology 2 in 2006-2012 based on a logistic regression model (a), Deforestation predicticve model of typology 2 in 2006-2012 based on a logistic regression model (b). 
Those areas that were predicted to have high deforestation probability in each typology should attract more serious attention from the government. Policy implications that could be taken including minimizing the development of road infrastructure that passes through wooded areas, both on the typology 1 and 2 . This is due to the proximity of the road is one of the factors that have contributed greatly to the chances of deforestation in the typology 1 and typology 2 .

Spatial modeling of deforestation on a large scale (Sumatra Islands) by using a typology of deforestation as done in this study, has generated different driving forces of deforestation on each typology. The results of this study confirmed that the triggering factors of deforestation in each locations were different and could not be generalized. The studies which simplify the population growth factor (Allen \& Barnes 1985; Meyer \& Turner 1992; Pahari \& Murai 1999 ) as the cause of deforestation on a global scale becomes inappropriate. The information that oversimplified the factors in deforestation can lead to policies that are less precise in handling the issue.

\section{Conclusion}

Typological deforestation in Sumatra Islands could be classified into 2 typologies, namely typology 1 with low deforestation rate and typology 2 with high deforestation rate. The number of farm households could be used as the determining factor to assign an area into appropriate typology. The spatial model of deforestation probability in typology 1 was influenced by driving factors such as elevation, distance from the road, number of farm households, while in typology 2 the deforestation probability was influenced by elevation, distance from the road, slope, distance from the river, and number of farm households. The spatial model of deforestation in 2000-2006 was sufficient to be used to predict the deforestation probability that occurred during 2006-2012 with an overall accuracy of $65.37 \%$ for typology 1 and $72.24 \%$ for typology 2 , respectively.

\section{References}

Abd El-Kawy OR, Rød JK, Ismail HA, Suliman AS. 2011. Land use and land cover change detection in the western Nile delta of Egypt using remote sensing data. Applied Geography 31(2):483-494. http://dx.doi.org/10. 1016/j.apgeog.2010.10.012.

Aguayo MI, Wiegand T, Azócar GD, Wiegand K, Vega CE. 2007. Revealing the driving forces of mid-cities urban growth patterns using spatial modeling: A case study of Los Ángeles, Chile. Ecology and Society 12(1):13.

Allen JC, Barnes DF. 1985. The causes of deforestation in developing countries. Annals of the association of American Geographers 75(2):163-184. http://dx.doi. org/10.1111/j.1467-8306.1985.tb00079.x.

Arekhi S. 2011. Modeling spatial pattern of deforestation using GIS and logistic regression: A case study of northern Ilam forests, Ilam Province, Iran. African
Journal of Biotechnology 10(72).

Arsanjani JJ, Helbich M, Kainz W, Darvishi Boloorani A. 2013. Integration of logistic regression, Markov chain and cellular automata models to simulate urban expansion. International Journal of Applied Earth Observation and Geoinformation 21:265-275. http://dx.doi.org/10.1016/j.jag.2011.12.014.

Churches CE, Wampler PJ, Sun W, Smith AJ. 2014. Evaluation of forest cover estimates for Haiti using supervised classification of landsat data. International Journal of Applied Earth Observation and Geoinformation 30:203-216. http://dx.doi.org/10.1016/ j.jag.2014.01.020.

de Almeida CM, Monteiro AMV, Câmara G, Soares-Filho BS, Cerqueira GC, Pennachin CL, Batty M. 2002. Empiricism and stochastics in cellular automaton modeling of urban land use dynamics. Centre for advanced spatial analysis [working paper series]. London: University Collage London.

Ediyanto, Mara NM, Satyahadewi N. 2013. Pengklasifikasian karakteristik dengan metode K-means custer analysis. Buletin Ilmiah Matematika Statistika dan Terapannya (Bimaster) 02(2):133-136.

Entwisle B, Rindfuss RR, Walsh SJ, Page PH. 2008. Population growth and its spatial distribution as factors in the deforestation of Nang Rong, Thailand. Geoforum; journal of physical, human, and regional geosciences 39(2):879-897. http://dx.doi.org/10.1016/j.geoforum.2 06.09.008.

Etter A, McAlpine C, Wilson K, Phinn S, Possingham H. 2006. Regional patterns of agricultural land use and deforestation in Colombia. Agriculture, Ecosystems \& Environment 114(2-4):369-386. http://dx.doi.org/10. 1016/j.agee.2005.11.013.

Gatto M, Wollni M, Qaim M.2015. Oil palm boom and landuse dynamics in Indonesia: The role of policies and socioeconomic factors. Land Use Policy 46:292-303. http://dx.doi.org/10.1016/j.landusepol.2015.03.001.

Geist HJ, Lambin EF. 2001. What Drives Tropical Deforestation? A meta-analysis of proximate and underlying causes of deforestation based on subnational case study evidence. Belgium: LUCC International Project Office.

Geist HJ, Lambin EF. 2002. Proximate causes and underlying driving forces of tropical deforestation. BioScience 52(2):143-150. http://dx.doi.org/ 10.1641/0006-3568(2002)052[0143:PCAUDF]2.0. $\mathrm{CO} ; 2$

Hosmer DW, Lemeshow S. 2000. Applied Logistic Regression. United States of America: Wiley. http://dx.doi.org/10.1002/0471722146. 
Huang Q-H, Cai Y-L, Peng J. 2007. Modeling the spatial pattern of farmland using GIS and multiple logistic regression: a case study of Maotiao River Basin, Guizhou Province, China. Environmental Modeling \& Assessment 12(1):55-61. http://dx.doi.org/10.1007/s10666-0069052-8.

Huiping Z, Hong J, Qinghua H. 2011. Landscape and water quality change detection in urban wetland: a postclassification comparison method with IKONOS data. Procedia Environmental Sciences 10:1726-1731. http://dx.doi.org/10.1016/j.proenv.2011.09.271.

Jaya INS. 2006. Teknik-Teknik Pemodelan Spasial dalam Pengelolaan Sumberdaya Alam dan Lingkungan. Bogor: IPB Press.

Khan SR, Khan SR. 2009. Assessing poverty-deforestation links: Evidence from Swat, Pakistan. Ecological Economics 68(10):2607-2618. http://dx.doi.org/10. 1016/j.ecolecon.2009.04.018.

Kumar R, Nandy S, Agarwal R, Kushwaha SPS. 2014. Forest cover dynamics analysis and prediction modeling using logistic regression model. Ecological Indicators 45:444-455. http://dx.doi.org/10.1016/j.ecolind.2014. 05.003 .

Lambin EF, Geist HJ, Lepers E. 2003. Dynamics of land-use and land-cover change in tropical regions. Annual Review of Environment and Resources 28:205-241. http://dx.doi.org/10.1146/annurev.energy.28.050302.10 5459.

Laurance WF, Sayer J, Cassman KG. 2014. Agricultural expansion and its impacts on tropical nature. Trends in ecology \& evolution 29(2):107-116. http://dx.doi. org/10.1016/j.tree.2013.12.001.

Linkie M, Smith R, Leader Williams N. 2004. Mapping and predicting deforestation patterns in the lowlands of Sumatra. Biodivers Conservation 13:1809-1818. http://dx.doi.org/10.1023/B:BIOC.0000035867.90891.e

Margono BA, Turubanova S, Zhuravleva I, Potapov P, Tyukavina A, Baccini A, Goetz S, Hansen MC. 2012. Mapping and monitoring deforestation and forest degradation in Sumatra (Indonesia) using Landsat time series data sets from 1990 to 2010. Environmental Research Letters 7(3):034010. http://dx.doi.org/10.1088 /1748-9326/7/3/034010.

Melati DN. 2012. Spatio-temporal data modeling in response to deforestation in Riau (A case study of small region in Riau Province, Indonesia) [thesis]. Germany: University of Munster.

Meyer WB, Turner BL. 1992. Human population growth and global land-use/cover change. Annual Review of Ecology and Systematics 23:39-61. http://dx.doi.org/10.1146/ annurev.es.23.110192.000351.
[MoF] Ministry of Forestry. 2012. Statistik Kehutanan Tahun 2011. Jakarta: Kementerian Kehutanan.

[MoF] Ministry of Forestry. 2014. Statistik Kehutanan Tahun 2013. Jakarta: Kementerian Kehutanan.

Mulyanto L, Jaya INS. 2004. Spatial analysis on forest degradation and deforestation: A case study in Duta Maju Timber, West Sumatera. Jurnal Manajemen Hutan Tropika 10(1):29-42.

Otukeia JR, Blaschke T. 2010. Land cover change assessment using decision trees, support vector machines and maximum likelihood classification algorithms. International Journal of Applied Earth Observation and Geoinformation 12(1):S27-S31. http://dx.doi. org/10.1016/j.jag.2009.11.002.

Pacheco P. 2006. Agricultural expansion and deforestation in lowland Bolivia: the import substitution versus the structural adjustment model. Land Use Policy 23(3):205-225. http://dx.doi.org/10.1016/j.landusepol. 2004.09.004.

Pahari K, Murai S. 1999. Modelling for prediction of global deforestation based on the growth of human population. ISPRS journal of photogrammetry and remote sensing 54(5):317-324. http://dx.doi.org/10.1016/S09242716(99)00032-5.

Prasetyo LB, Kartodihardjo H, Okarda B, Adiwibowo S, Setiawan Y. 2009. Spatial model approach on deforestation of Java Island, Indonesia. Journal of Integrated Field Science 6: 37-44.

Richards JA, Richards J. 1999. Remote Sensing Digital Image Analysis. Berlin: Springer. http://dx.doi.org/10. 1007/978 -3-662-03978-6.

Romijn E, Ainembabazi JH, Wijaya A, Herold M, Angelsen A, Verchota L, Murdiyarso D. 2013. Exploring different forest definitions and their impact on developing REDD+ reference emission levels: A case study for Indonesia. Environmental Science \& Policy 33:246-259. http://dx.doi.org/10.1016/j. envsci.2013.06.002.

Rudel TK. 2007. Changing agents of deforestation: From state-initiated to enterprise driven processes, 1970-2000. Land Use Policy 24(1):35-41. http://dx.doi.org/10. 1016/j.landusepol.2005.11.004.

Setiawan Y, Lubis MI, Yusuf SM, Prasetyo LB. 2015. Identifying change trajectory over the Sumatra's forestlands using moderate image resolution imagery. Procedia Environmental Sciences 24:189-198. http://dx.doi.org/10.1016/j.proenv.2015.03.025.

Soares C, Stevenson A. 2009. Cruise Oxford English Dictionary. Oxford: Oxford University Press.

Solano R, Didan K, Jacobson A, Huete A. 2010. MODIS Vegetation Index User's Guide (MOD13 Series) 
Vegetation Index and Phenology Lab. The University of Arizona.

Sumargo W, Nanggara SG, Nainggolan FA, Apriani I. 2011. Potret Keadaan Hutan Indonesia Periode Tahun 2000-2009. Jakarta: Forest Watch Indonesia.

van Beukering PJH, Cesar HSJ, Janssen MA. 2003. Economic valuation of the Leuser National Park on Sumatra, Indonesia. Ecological Economics 44(1):43-62. http://dx.doi.org/10.1016/S0921-8009(02)00224-0.

Wedastra IBK, Shapiro A, Apriani E, Widiastomo T. 2013.
Sistem Pemantauan Penutupan Lahan Pulau dan Wilayah (Pemanfaatan Teknologi Penginderaan Jauh-MODIS). Jakarta: WWF INDONESIA.

Were KO, Dick ØB, Singh BR. 2013. Remotely sensing the spatial and temporal land cover changes in Eastern Mau forest reserve and Lake Nakuru drainage basin, Kenya. Applied Geography 41:75-86. http://dx.doi.org/ 10.1016/j.apgeog.2013.03.017.

Whitten T, Damanik S J, Anwar J, Hisyam N. 2000. The Ecology of Sumatra. Singapore: Periplus. 